\title{
Genetic parameters in a clonal test of Tectona grandis in Mato Grosso, Brazil
}

\author{
Ana Carolina Pereira $\oplus^{1 *}$ Sidney Fernando Caldeira $\odot^{1}$ Daniele Aparecida Alvarenga Arriel ${ }^{1}$
}

${ }^{1}$ Universidade Federal do Mato Grosso, Av. Fernando Corrêa da Costa, 2367, Boa Esperança, CEP 78060-900, Cuiabá, MT, Brasil
${ }^{2}$ Universidade Federal de Uberlândia, Rodovia LMG 746, Km 01, s/nº CEP: 38.500-000, Monte Carmelo - MG, Brasil

Original Article
*Corresponding author:
carolpereira1297@gmail.co
m
Keywords:
Forest tree breeding
Teak
Selection
Palavras-chave:
Melhoramento
florestal
Teca
Seleção
Received in
2020/10/02
Accepted on
Publ/07/01
Published in

ABSTRACT: Teak (Tectona grandis) is a high-value timber species in tropical regions. In Brazil, although teak has a high productivity, there are few studies related to its genetic improvement. This work aimed to estimate genetic parameters and evaluate the potential gains of selection in a clonal test of teak installed in the state of Mato Grosso, Brazil. The experiment was in a randomized block design with five replications, $3 \times 3 \mathrm{~m}$ spacing, 22 treatments, and six individuals per plot. After five years, the genotypes were evaluated for survival $(\mathrm{S})$, tree total height $(\mathrm{H})$, and girth at breast height $(1.3 \mathrm{~m}$; $\mathrm{GBH})$. Selection for $\mathrm{S}$ and GBH was significant and feasible. For $\mathrm{H}$, the result was not significant. The genetic parameters of clonal mean heritability and accuracy were of moderate magnitude for $\mathrm{S}$ and $\mathrm{GBH}$ and low for $\mathrm{H}$. To the best of our knowledge, this was the first work to estimate genetic parameters in a clonal teak test in the field in Brazil.

\section{Parâmetros genéticos em um teste clonal de Tectona grandis no Mato Grosso, Brasil}

RESUMO: A teca (Tectona grandis) é uma espécie madeireira de alto valor nas regiões tropicais. No Brasil, embora a teca apresente alta produtividade, existem poucos estudos relacionados ao seu melhoramento genético. Esse trabalho teve como objetivo estimar parâmetros genéticos e avaliar potenciais ganhos de seleção em um teste clonal de teca instalado no estado de Mato Grosso, Brasil. O experimento foi instalado em delineamento de blocos ao acaso, com cinco repetições, espaçamento de $3 \times 3 \mathrm{~m}, 22$ tratamentos e parcelas com seis indivíduos. Aos cinco anos, os clones foram avaliados quanto a sobrevivência (SOB), altura total $(\mathrm{HT})$ e circunferência à altura do peito $(1,3 \mathrm{~m}$; CAP). Houve significância e viabilidade de seleção para SOB e CAP. Para HT o resultado não foi significativo. As herdabilidades na média de clone e as acurácias foram de magnitude moderada para SOB e CAP e baixa para HT. Este, ao que parece, é o primeiro trabalho que estima parâmetros genéticos em um teste clonal de teca em campo no Brasil. 


\section{Pereira et al.}

\section{Introduction}

Tectona grandis, popularly known as teak, is a timber specie that occurs naturally in India, Myanmar, Thailand, and Laos. Currently, teak is cultivated in several regions of Africa and South and Central America (Nocetti et al. 2011), with an estimated planting area ranging from 4.25 to 6.89 million hectares (Kollert and Kleine 2017).

In Brazil, teak was commercially introduced in the state of Mato Grosso in the 1970's, in the region of the city of Cáceres. After its adaptation, there was a growing interest in its cultivation due to the high market value of its wood. Currently, teak is the fifth most planted forest species in the country, with around 93,957 ha (IBA 2019). In addition to its rapid growth, the density and beauty of its wood make teak appreciated for its use in luxury furniture and shipbuilding (Rocha et al. 2015). Furthermore, its timber is considered an alternative to others of high economic value, such as that of Swietenia macrophylla King, the Brazilian mahogany, and that of Torresea acreana Ducke, the cherry tree (Pelissari et al. 2013).

It is estimated that the most significant introduction of teak germplasm in Latin America occurred in 1913, with the production of seedlings from Tenasserim, Myanmar (Keogh 1979). In Brazil, the first plantings were established with provenances from Tenasserim, brought from Trinidad and Tobago (Schuhl and Paludzyszyn Filho 2010). Subsequently, most of the plantings in the country came from seeds of the trees remaining from the original plantings (Badilla and Murillo 2011).

Until the mid-2000s, the propagation teak in Brazil was predominantly seminal. In 2003, genotypes from the teak breeding program of Sabah, Malaysia, were introduced, and then the first clonal plantations of the species were established in the country (Camino and Morales 2013). Due to homogeneity and increased productivity in the volume of wood, the installation of clonal plantations has become the most adopted practice with teak in Brazil (Costa et al. 2015).

Although clonal plantations have advantages, genetic testing, such as clonal tests, is essential in breeding programs because it allows the establishment of the best strategies to be taken. From these tests, it is possible to evaluate the genetic variability of the genotypes, to estimate important genetic parameters, and to evaluate the adaptation of the genotypes in different planting regions. In Brazil, there are still scarce studies related to the improvement of the species, especially those that evaluate genetic tests, the magnitude of genetic parameters, and the correlations between traits and age of selection (Costa et al. 2007).

Thus, the objective of this work was to estimate genetic parameters and evaluate potential gains of selection in a clonal test of $T$. grandis, at the age of five, in the municipality of Nossa Senhora do Livramento, in Mato Grosso, Midwest Brazil.

\section{Material and Methods}

In November 2013, the clonal test was installed in the county of Nossa Senhora do Livramento, state of Mato Grosso, Brazil, $73 \mathrm{~km}$ southwest of the capital Cuiabá, in the geographical coordinates $16^{\circ} 12^{\prime} 3.35^{\prime \prime} \mathrm{S}$ and $56^{\circ} 22^{\prime} 46.56^{\prime \prime} \mathrm{O}$.

The region's climate is characterized as tropical (Aw), according to the Köppen classification, with well-defined dry and rainy seasons, average rainfall of $1,300 \mathrm{~mm}$. year-1, average annual temperature of $25^{\circ} \mathrm{C}$, minimum averages of $20^{\circ} \mathrm{C}$, maximum average of $32^{\circ} \mathrm{C}$, and relative humidity of 70 to $75 \%$ (Campello Júnior et al. 1991). The characteristic relief is gently undulating, and the soil is classified as Eutrophic Haplossol with a sandy loam texture (Embrapa 2006).

Before the implementation of the experiment, the area was used as pasture, which showed natural bush regeneration, which was removed before installing the test. The soil was subjected to subsoiling at a depth of $50 \mathrm{~cm}$, followed by the passage of a leveling harrow. Subsequently, the cuttings were planted in individual pits distributed with $3 \times 3 \mathrm{~m}$ spacing. After test installation, the silvicultural treatments recommended for the species, such as replanting, thinning, and pruning, were not carried out for internal reasons related to the company.

The tested genotypes were obtained from 19 potential clones selected from trees in seminal plantations from three companies in Mato Grosso, Brazil. In addition, two commercial clones and seminal plants were used as controls, totaling 22 treatments. The trial was installed under a randomized block design with five replications. In each plot, six individuals of each genotype were planted in the form of three pairs ('parejas'), as proposed by Badilla and Murillo (1999). These authors recommended this kind of delineation in experiments for the production of sawn timber, as occurs with teak. Its main objective is to evaluate timber species for a long period, before and after thinning, leaving only one plant in the pair or 'pareja'. It allows the experiment to remain balanced and with approximately equidistant plants after thinning and tends to minimize the effects of differentiated competition after thinning (Badilla and Murillo 1999).

At five years of age, without thinning, the clones were evaluated for the following characteristics: survival $(\mathrm{S})$, tree total height $(\mathrm{H})$, and girth at breast height $(1.3 \mathrm{~m} ; \mathrm{GBH}) . \mathrm{S}$ was expressed as the percentage of individuals remaining in relation to the number of individuals planted. $\mathrm{H}$ was recorded 
in meters with a hypsometer and GBH in centimeters with a graduated tape.

Estimates of the variance components and the genetic parameters were obtained through the restricted maximum likelihood, applied to the mixed linear model (REML), and the prediction of the genetic values by the best linear unbiased predictor methodology (BLUP), using the genetic-statistical software SELEGEN (Resende 2002).

The model was: $\mathrm{y}=\mathrm{Xr}+\mathrm{Zg}+\mathrm{Wp}+\mathrm{e}$, in which $\mathrm{y}$ is the vector of data, $\mathrm{r}$ is the vector of fixed effects of the repetition added to the general average, $\mathrm{g}$ is the vector of random effects of genotype, $\mathrm{p}$ is the vector of random effects of plots, and e is the vector of random effects of error. The capital letters represent the incidence matrices for each effect.

The effects of clones and plots were tested through the analysis of deviance by the chi-square test at a 1 and 5\% probability, comparing the values of deviance with and without the respective effect (Likelihood ratio rest-LTR).

The following components of variance and genetic parameters were estimated: genotypic variance; plot variance; environmental variance; phenotypic variance; coefficient of determination of plot effect; clonal mean heritability; coefficient of individual genetic variation; coefficient of experimental variation; selective accuracy; and relative coefficient variation.

To evaluate potential gains of selection, the average of the clones were ranked for each of the variables studied, and the five best genotypes were selected. Subsequently, the expected genetic gains were estimated.

\section{Results}

The effects of clones were significant for the variables' survival (S) and girth at breast height $(1.3 \mathrm{~m}$; GBH) (Table 1), indicating that at least one treatment differed from the others and consequently demonstrating the possibility of selection for these variables. For the tree total height $(\mathrm{H})$, no significant differences were obtained for the effects of clones at five years old. New evaluations at later ages will be carried out to assess whether or not this trend continues for this trait.

The clonal mean heritability for $\mathrm{S}$ and $\mathrm{GBH}$ was 0.39 and 0.36 , respectively, classified as a moderate magnitude according to Resende (2002b). The clonal mean heritability estimate for tree total height $(\mathrm{H})$ was low (0.01) (Resende 2002b).

The estimated accuracy (Table 2) was of moderate magnitude for $\mathrm{S}(0.62)$ and $\mathrm{GBH}(0.60)$, and of low magnitude for $\mathrm{H}(0.10)$, according to the classification of Resende (2002b). Therefore, the highest clonal mean heritability values were for the variables $\mathrm{S}$ and $\mathrm{GBH}$ (Table 2) due to the relationship of these parameters with accuracy, which was obtained by means of the square root of the clonal mean heritability.

The $\mathrm{CVg} / \mathrm{CVe}$ ratio is represented by the relative coefficient variation (RCV) and indicates security in the selection process when it presents values close to or greater than one (Vencovsky and Barriga 1992). However, for all studied variables, RCV was lower than one, which was expected due to the high values found for $\mathrm{CVe}$. However, the variables $\mathrm{S}(0.36)$ and $\mathrm{GBH}(0.34)$ showed moderate values for this parameter, indicating prospects of gain with selection.

The commercial clones 3 and 22 were in the first position for all tested variables (Table 3 and Table 4).

The genotype of seminal origin (12) was in the $14^{\circ}$ position for $\mathrm{S}, 20^{\circ}$ for $\mathrm{H}$, and $21^{\circ}$ for $\mathrm{GBH}$ (Table 4). The mean values of $\mathrm{H}$ and $\mathrm{GBH}$ for the studied clones were $7.21 \mathrm{~m}$ and $39.58 \mathrm{~cm}$, respectively (Table 3 ).

The coefficient of individual genetic variation between clones $(\mathrm{CVg}$ in \%) ranged from $14.19 \%$ for $\mathrm{S}$ to $0.75 \%$ for $\mathrm{H}$ (Table 2). This parameter expresses the amount of existing genetic variability for each trait evaluated, and the higher the $\mathrm{CVg}$ values, the easier it will be to select the best individuals (Silva 2014). The coefficient of experimental variation $(\mathrm{CVe}$ in \%) ranged from $39.38 \%$ for $\mathrm{S}$ to $16.02 \%$ for $\mathrm{H}$ (Table 2 ).

Table 1. Analysis of Deviance (DEV) by the likelihood ratio test (LTR) for survival (S), total tree height (H) and girth at breast height $(1.3 \mathrm{~m} ; \mathrm{GBH})$ in a Tectona grandis clonal test, at five years of age in the state of Mato Grosso, Brazil.

\begin{tabular}{ccccccc}
\hline Efect & \multicolumn{2}{c}{ S } & \multicolumn{2}{c}{ H } & \multicolumn{2}{c}{ GBH } \\
\cline { 2 - 7 } & Dev. & LRT & Dev. & Dev. & Dev. & LRT \\
\hline Clone & 408.66 & $10.18^{* *}$ & 629.14 & $0.01^{\text {ns }}$ & 2519.03 & $8.26^{* *}$ \\
Plot & 409.22 & $9.62^{* *}$ & 723.56 & $94.43^{* *}$ & 2552.15 & $41.3^{* *}$ \\
Full model & 418.84 & & 629.13 & & 2510.77 & \\
\hline
\end{tabular}

*Significant by chi-square test at $5 \%(3.84)$; ** Significant by chi-square test at $1 \%(6.63)$ and no significance (ns). 
Table 2. Estimates of components of variance and genetic parameters for survival (S), total tree height (H) and girth at breast height $(1.3 \mathrm{~m}$; GBH) for Tectona grandis clones, at the age of five in the state of Mato Grosso, Brazil.

\begin{tabular}{cccc}
\hline Genetic parameters & S & H & GBH \\
\hline Genotypic variance & 0.01 & 0.002 & 6.42 \\
Plot variance & 0.03 & 1.13 & 40.64 \\
Environmental variance & 0.15 & 0.58 & 43.76 \\
Phenotypic variance & 0.19 & 1.72 & 90.83 \\
Coefficient of determination of effects of plots & 0.16 & 0.66 & 0.44 \\
Clonal mean heritability & 0.39 & 0.01 & 0.36 \\
Selective accuracy & 0.62 & 0.10 & 0.60 \\
Coefficient of individual genetic variation $(\mathrm{CVg}$ in $\%)$ & 14.1 & 0.75 & 6.86 \\
Coefficient of experimental variation $(\mathrm{CVe}$ in $\%)$ & 39.3 & 16.02 & 20.12 \\
Relative coefficient of variation (RCV). & 0.36 & 0.04 & 0.34 \\
\hline Average & 0.72 & 7.20 & 36.93 \\
\hline
\end{tabular}

Table 3. Estimates of genetic gains for survival $(\mathrm{S})$, total tree height $(\mathrm{H})$ and girth at breast height $(1.3 \mathrm{~m}$; GBH) in a Tectona grandis clonal test, with 5-year-old trees in the state of Mato Grosso, Brazil.

\begin{tabular}{cccccccc}
\hline \multirow{2}{*}{ Ranking } & \multicolumn{2}{c}{$\mathbf{S}$} & \multicolumn{2}{c}{$\mathbf{H}$} & \multicolumn{2}{c}{ GBH } \\
\cline { 2 - 8 } & Clone & Gain $(\%)$ & Clone & Gain $(\%)$ & Clone & Gain $(\%)$ \\
\hline $1^{\circ}$ & 22 & 14.318 & 3 & 0.214 & 3 & 11.709 \\
$2^{\circ}$ & 3 & 14.318 & 22 & 0.186 & 22 & 10.917 \\
$3^{\circ}$ & 20 & 14.070 & 16 & 0.161 & 20 & 9.188 \\
$4^{\circ}$ & 9 & 13.451 & 18 & 0.146 & 8 & 8.125 \\
$5^{\circ}$ & 6 & 12.528 & 8 & 0.133 & 18 & 7.178 \\
\hline $\begin{array}{c}\text { General mean for the selected } \\
\text { clones }\end{array}$ & \multicolumn{2}{|c}{$81.7 \%$} & & \multirow{2}{*}{$7.21 \mathrm{~m}$} & \multicolumn{2}{c}{$39.58 \mathrm{~cm}$} \\
\hline
\end{tabular}

Subtitle: $3,6,8,9,16,18,20,22=$ denomination of the selected clones.

\section{Discussion}

Although the literature reports studies related to the estimation of genetic parameters in clonal tests of teak in other countries (Callister and Collins 2008; Monteuuis et al. 2011; Naranjo et al. 2012; Goh et al. 2013), to the best of our knowledge, this is the first study with estimates of genetic parameters in a clonal teak test in the field in Brazil. Therefore, this information can assist in the decision making of the best strategies in teak breeding programs in this country.

For the three traits studied, the values of the coefficient of environmental variation were high when compared with the values of the coefficients of genetic variation. Personal information from company technicians reported that the experiment was purposely implemented in a place with a reduced number of silvicultural treatments to assess the performance of clones in these conditions. These circumstances likely underestimated the productive capacity of the clones and influenced the estimates of the components of variance and genetic parameters due to the high environmental influence. In addition, the analyses were performed considering the seminal genotypes increased the $\mathrm{CVe}$ and consequently decreased the accuracy and heritability (data not shown).

The moderate values of clonal mean heritability found for GBH were similar to those observed in the literature for clonal tests of teak at three to seven years of age in Malaysia, in which the clonal mean heritability for GBH ranged from 0.29 to 0.33 (Goh et al. 2013). In Costa Rica, in a fouryear clonal test, the estimated values were 0.36 for GBH (Naranjo et al. 2012). In another test in Malaysia, the heritability values for GBH showed a gradual increase with age but remained lower after 106 months of age ( 9 years), being 0.24 (Monteuuis et al. 2011). However, in that case, the authors estimated heritability in the broad sense of individual 
plants. Then, when estimating the average heritability values of clones, there was likely a greater magnitude.

Regarding the height, the clones' mean heritability were practically null. Higher values of this parameter were reported in the literature by Goh et al. (2013) in a study with teak clones, in which the clonal mean heritability for height was of moderate magnitude (0.34 and 0.56 at four and six years, respectively).

Table 4. Ranking of the 22 clones and their respective means for survival $(\mathrm{S})$, total tree height $(\mathrm{H})$, and girth at breast height $(1.3 \mathrm{~m} ; \mathrm{GBH})$ in a Tectona grandis clonal test, with 5-year-old trees in the state of Mato Grosso, Brazil.

\begin{tabular}{ccccccc}
\hline Order & & S & \multicolumn{3}{c}{ H } & \multicolumn{2}{c}{ GBH } \\
\hline 1 & Clone & Mean & Clone & Mean & Clone & Mean \\
2 & 22 & 0.8303 & 3 & 7.2181 & 3 & 41.2620 \\
3 & 3 & 0.8303 & 22 & 7.2140 & 22 & 40.6768 \\
4 & 20 & 0.8250 & 16 & 7.2107 & 20 & 39.0541 \\
5 & 9 & 0.8104 & 18 & 7.2101 & 8 & 38.7602 \\
6 & 6 & 0.7904 & 8 & 7.2088 & 18 & 38.1881 \\
7 & 18 & 0.7904 & 5 & 7.2085 & 16 & 37.8732 \\
8 & 17 & 0.7904 & 17 & 7.2074 & 17 & 37.7341 \\
9 & 4 & 0.7626 & 6 & 7.2073 & 9 & 37.1952 \\
10 & 13 & 0.7626 & 20 & 7.2048 & 7 & 36.9675 \\
11 & 8 & 0.7505 & 14 & 7.2038 & 1 & 36.9296 \\
12 & 19 & 0.7419 & 1 & 7.2031 & 14 & 36.7564 \\
13 & 14 & 0.7305 & 11 & 7.2014 & 15 & 36.6970 \\
14 & 5 & 0.7305 & 15 & 7.2008 & 5 & 36.6156 \\
15 & $12 *$ & 0.7106 & 21 & 7.2003 & 10 & 36.3844 \\
16 & 10 & 0.6906 & 7 & 7.1974 & 13 & 36.2400 \\
17 & 1 & 0.6906 & 13 & 7.1973 & 11 & 36.0896 \\
18 & 11 & 0.6706 & 9 & 7.1971 & 6 & 35.5065 \\
19 & 15 & 0.6706 & 10 & 7.1953 & 2 & 35.3503 \\
20 & 21 & 0.6587 & 4 & 7.1947 & 21 & 35.1798 \\
21 & 16 & 0.5963 & $12 *$ & 7.1939 & 4 & 34.7342 \\
22 & 2 & 0.5908 & 2 & 7.1938 & $12 *$ & 34.7226 \\
\hline & 7 & 0.5547 & 19 & 7.1906 & 19 & 33.6976 \\
\hline
\end{tabular}

* Seminal genotype

Survival is a feature of great importance in genetic tests, as it is used as an indicator of the adaptation of the genetic material tested to the place where it was installed and its edaphoclimatic conditions. When compared to other studies, the average survival rate of $72 \%$ found in the studied clonal test was considered relatively low. In Sabah, Malaysia, in a clonal test with teak aged between five and 60 years, the average mortality was less than $10 \%$ (Goh et al. 2013). Pelissari et al. (2013) reported $95 \%$ survival in seminal stands of the species evaluated from two to 10 years in sites adjacent to the present trial. However, as previously mentioned, replanting was not performed in the test, which possibly reduced the survival rate.

Even with registered survival, the considerable values of clonal mean heritability and the significance of this variable in the analysis of deviance is an indication that some of the tested materials had greater adaptation to the location, since there were materials with survival rates above $80 \%$ and materials with rates below $35 \%$ (Table 4). Thus, genotypes with the highest survival rate are the most suitable for the implantation of commercial stands in sites with similar conditions.

The average GBH was similar to that recorded by Silva et al. (2014) in a seminal teak plantation at the age of five, with $12.5 \mathrm{~cm}$ in diameter at breast height $(1.3 \mathrm{~m}$; DBH), equivalent to 39.26 $\mathrm{cm}$ in GBH. Regarding height, an average value of $12.6 \mathrm{~m}$ was reported by Baretta (2016) in a clonal teak experiment in Cáceres-MT, at 4.5 years old. Thus, it is possible to verify that, although the material of the current study was clonal, it was not necessarily superior to the material of seminal origin, since what guarantees the superiority of the clone is a better quality genotype selected based on a certain criterion. 
The relatively lower values found for the mean $\mathrm{H}$ can be explained by the condition of the site where the clonal test was installed. According to Pelissari et al. (2013), who worked with seminal stands in the same area, the plots adjacent to the experimental area were classified by the dominant height at all sites of medium to low productivity. Thus, the height trait was likely the most affected, due to the fact that the dominant height was the main indicator of site quality (Pissinin and Schneider 2017).

One of the great challenges of breeding programs today is to overcome the commercial clones planted (Santos et al. 2015; Nunes et al. 2016). In this trial, the commercial clones $(3,22)$ were superior to other tested materials. However, the genotypes in the test showed values close to the commercial ones (Table 4) and can help to increase the diversity of genetic materials commercially planted in the country.

It is important to highlight that the data were collected in a clonal test five years after planting and that the estimated period for the rotation of teak stands in Brazil is around 25 to 30 years (Macedo et al. 2005) or between seven and 18 years for the socalled young teak (Avelino 2012), with the application of silvicultural treatment, such as thinning and pruning, in both systems. Thus, the feasibility of early selection at this age should be assessed, as is the case for other forest species such as eucalyptus (Pinto et al. 2014; Moraes et al. 2014; Queiroz et al. 2019), yerba mate (Wendling et al. 2018), and Aroeira (Carderalli et al. 2013).

In addition, for species used for sawmill wood production, such as teak, it is important to evaluate other traits related to wood quality (Naranjo et al. 2012; Arce and Moya 2015), such as measurement, heartwood /sapwood proportion, and density, considering that these are the main resources that influence the quality and value of sawn wood (Lemos et al. 2019).

\section{Conclusions}

Clones of Tectona grandis from selected matrices of seminal plantations in Mato Grosso had genetic variability and selection viability for girth at breast height $(1.3 \mathrm{~m}$; GBH) and survival (S) variables.

Of the tested materials, commercial clones were in the top positions for all variables tested, and the control, of seminal origin, was in the last ranking positions for all variables.

\section{Acknowledgements}

The authors thank Teca do Brasil Florestal LTDA for providing data and for field assistance.

\section{References}

Arce N, Moya R (2015) Wood characterization of adult clones of Tectona grandis growing in Costa Rica. Cerne, 21(3): 353-362. doi: $10.1590 / 0104776020152103175$.

Avelino EF (2012) Avaliação da madeira de teca jovem (Tectona grandis L.f.) visando uso em movelaria. Dissertation, Rural Federal University of Rio de Janeiro. 88p.

Badilla Y, Murillo O (2011) Avances en el mejoramiento genético de La teca em Genfores, Costa Rica. Conferencia Mundial de Teca patrocinada por CATIE, FAO y Teak net (San José, CR, 31 oct.- 2 nov).

Badilla Y, Murillo O (1999) Propuesta de un diseño de parcela para La investigación con espécies nativas en Costa Rica. Kurú, 25: 4-5.

Baretta MC (2016) Crescimento e caracterização morfológica de clones de teca no sudoeste de Mato Grosso. Dissertation, Universidade Federal de Mato Grosso, Cuiabá- MT. 85p.

Callister AN, Collins SL (2008) Genetic parameter estimates in a clonally replicated progeny test of teak (Tectona grandis Linn. f.). Tree Genetics \& Genomes, 4: 237-245. doi: 10.1007/s11295-0070104-2.

Camino R, Morales JP (2013) Las plantaciones de teca en América Latina: Mitos y realidades. Turrialba: CATIE, 2013. 392 p. (Série técnica: Informe técnico, 397).

Campello Júnior JH, Priante filho N, Caseiro FT (1991) Caracterização macroclimática de Cuiabá. In: Anais do III Encontro Nacional de Estudos sobre o Meio Ambiente, Londrina: UEL/NEMA.

Carderalli A, Costa RB, Azevedo LPA, Ribeiro ES, Batista BMF, Sousa RATM (2013) Seleção precoce em progênies de meios irmãos de Myracrodruon urundeuva Fr. All. via Metodologia Reml/Blup. Ambiência Guarapuava (PR), 9(3): 605-617. doi: 10.5935/ambiencia.2013.03.10.

Costa RB, Resende MDV, Silva VSM (2007) Experimentação e seleção no melhoramento genético de Teca (Tectona grandis L. f.). Floresta e Ambiente, 14(1): 76-92.

Costa RB, Martinez DT, Chichorro JF, Bauer MO, Cezana DP, Souza TR (2015) Desempenho de progênies no pré- melhoramento de Tectona grandis L. f no estado do Espírito Santo. Scientia florestalis, 43: 211-216. 
EMBRAPA Centro Nacional de Pesquisa de Solos (2006). Sistema Brasileiro de Classificação de Solos. 2: 306. ed. Rio de Janeiro: Embrapa.

Goh DKS, Japarudin Y, Alwi A, Lapammu M, Flori A, Monteuuis O (2013) Growth differences and genetic parameter estimates of 15 teak (Tectona grandis L.f.) genotypes of various ages clonally propagated by microcuttings and planted under humid tropical condition. Silva e Genetica, 62: 196206. doi: 10.1515/sg-2013-0024.

IBA, Indústria Brasileira de Árvores (2019) Relatório IBA 2019. Brasília: IBA.

Keogh R (1979) Does teak have a future in tropical America? A survey of Tectona grandis in the Caribbean, Central America, Venezuela and Colombia. Unasylva, 31: 13-19.

Kollert W, Kleine M (2017) The global teak study. analysis, evaluation and future potential of teak resources. International Union of Forest Research Organisations (IUFRO) World Series, Vienna.

Lemos JAS, Mendes MCS, Madi JPS, Pereira BLC, Oliveira AC (2019) Influência do método de propagação na produção e qualidade da madeira de Tectona grandis. Advances in Forestry Science, 6(3): 761-765. doi: 10.34062/afs.v6i3.8183.

Macedo RLG, Gomes JE, Venturin N, Salgado BG (2005) Desenvolvimento inicial de Tectona grandis L.f. (teca) em diferentes espaçamentos no município de Paracatu, MG. Cerne, 11(1): 61-69.

Monteuuis O, Goh DKS, Garcia C, Alloysius D, Gidiman J, Bacilieri R, Chaix G (2011) Genetic variation of growth and tree quality traits among 42 diverse genetic origins of Tectona grandis planted under humid tropical conditions in Sabah, East Malaysia. Tree Genetics \& Genomes, 7:1263-1275. doi: 10.1007/s11295-011-0411-5.

Moraes CB, Brizolla TF, Teixeira LG, Zimback L, Tamburassi EV, Chaves R, Moraes MLT, Moti ES (2014) Estimativas dos parâmetros genéticos para seleção de árvores de Eucalytus. Scientia Forestalis, 42(104): 623-629.

Naranjo SS, Moya R, Chauhan S (2012) Early genetic evaluation of morphology and some wood properties of Tectona grandis L. Clones. Silvae Genetica, 61: 58-65. doi: 10.1515/sg-2012-0008.

Nocetti M, Rozenberg P, Chaix G, Macchioni N (2011) Provenance effect on the ring structure of teak (Tectona grandis L.f.) wood by X-ray micro densit o metry. Annals of Forest Science, 68: 13751383. doi: 10.1007/s13595-011-0145-4.
Nunes ACP, Santos GA, Resende MDV, Silva LD, Higa A, Assis TF (2016) Estabelecimento de zonas de melhoramento para clones de eucalipto no Rio Grande do Sul. Scientia Forestalis, 4(111): 563-574. dx.doi.org/10.18671/scifor.v44n111.03.

Pelissari AL, Caldeira SF, Drescher R (2013) Desenvolvimento Quantitativo e Qualitativo de Tectona grandis L.f. em Mato Grosso. Floresta $e$ Ambiente, 20(3): 371-383. doi: 10.4322/floram.2013.027.

Pinto DS, Resende RT, Mesquita AGC, Rosado AM, Cruz CD (2014) Seleção precoce para características de crescimento em testes clonais de Eucalyptus urophylla. Scientia Forestalis, 42: 251-257.

Pissinin LZ, Schneider PR (2017) Tendências de crescimento em altura dominante de dois clones de Eucalyptus saligna Smith implantados em distintas condições de solo. Ciência Florestal, 27(1): 263275. doi: 10.5902/1980509826465.

Queiroz MM, Arriel DAA, Tsukamoto AA, Oliveira OE, Moraes PM, Skowronski L, Costa RB (2019) Early selection in Eucalyptus camaldulensis Dehnh. progenies in Savanna, Brazil. African Journal of Biotechnology, 18(16): 347-351. doi: 10.5897/AJB2018.16729.

Resende MDV (2002) Software Selegen REML/ BLUP. Colombo: EMBRAPA Florestas. Documentos 67p.

Resende MDV (2002b) Genética biométrica $e$ estatística no melhoramento de plantas perenes. Brasília: Embrapa Informação Tecnológica. 975p.

Rocha HF, Leonardo FVS, Oliveira AC (2015) Plantios comerciais de Tectona grandis L. f. no Brasil. Multitemas, 48: 9-28. doi: 10.20435/multi.v0i48.137.

Santos GA, Resende MDV, Silva LD, Higa A, Assis TF (2015) Interação genótipos x ambientes para produtividade de clones de Eucalyptus l'hér. no estado do Rio Grande do Sul. Revista Árvore, 39(1): 81-91. dx.doi.org/10.1590/010067622015000100008

Schuhli GS, Paludzyszyn Filho E (2010) O cenário da silvicultura de teca e perspectivas para o melhoramento genético. Pesquisa Florestal Brasileira, 30: 217-230. doi: 10.4336/2010.pfb.30.63.217.

Silva FR, Silva VSM, Miranda SO (2014) Crescimento de Tectona grandis em uma plantação no município de Alta Floresta, Mato Grosso. 
FLORESTA, 44(4): 577-588. doi: 10.5380/rf.v44i4.29699.

Silva JC (2014) Análise univariada e multivariada em progênies de Eucalyptus camaldulensis Dehn em Mato Grosso. Dissertation, Universidade Federal de Mato Grosso, Cuiabá- MT.79p.

Vencovsky R, Barriga P (1992) Genética biométrica no fitomelhoramento. Ribeirão Preto: Sociedade Brasileira de Genética. 496p.

Wendling I, Sturion JA, Stuepp CA, Reis CAF, Ramalho MAP, Resende MDV (2018) Early selection and classification of yerba mate progênies. Pesquisa Agropecuária Brasileira, 53: 279-286. doi: 10.1590/s0100-204x2018000300002. 